\title{
Effect of argon- and nitrogen-based modified atmosphere packaging on shiitake mushroom quality
}

\author{
Jong-Jin Park, Jae-Jun Lee, Ibukunoluwa Fola Olawuyi, Wonyoung Lee* \\ School of Food Science and Biotechnology, Kyungpook National University, Daegu 41566, Korea
}

\begin{abstract}
The effect of modified atmosphere packaging (MAP) on shiitake mushroom quality was investigated using different types of gases (air, nitrogen and argon). The mushrooms were placed in a composite polyethylene-polyamide package, and then the package was evacuated, flushed with desired gas, and heat-sealed. The packaged mushrooms were stored at 5 and $15^{\circ} \mathrm{C}$ for 21 days. During storage, the color, texture, gas composition, weight loss, microorganism count and polyphenol oxidase (PPO) activity were measured. Carbon dioxide production, weight loss, color change, PPO activity, microorganism count and decline of hardness were more inhibited at $5^{\circ} \mathrm{C}$ than at $15^{\circ} \mathrm{C}$. The MAP used did not affect the weight loss or microbial count. However, mushroom in the argon (Ar) MAP had the lowest carbon dioxide production followed by those in the nitrogen (N) MAP and then the air filled control packaging (C). At $15^{\circ} \mathrm{C}$, the $L^{*}$ value of the mushroom gills in the Ar and $N$ MAP maintained throughout the storage time. Of particular note, mushrooms in Ar MAP retained hardness at 5 and $15^{\circ} \mathrm{C}$, unlike those of the control. PPO activity was inhibited by the $\mathrm{Ar}$ and $\mathrm{N}$ MAP at $15^{\circ} \mathrm{C}$. Based on these results, the quality of shiitake mushrooms was best preserved during storage by the Ar MAP.
\end{abstract}

Key words : modified atmosphere packaging, shiitake mushroom, argon, nitrogen

\section{Introduction}

Shiitake mushrooms (Lentinula edodes), called 'Pyogo' in Korea, 'Hyanggo' in China, 'Shiitake' in Japan, and 'oak mushroom' in the Western part of the world (1), are edible mushrooms that have excellent nutritional value, being rich essential amino acids and proteins. They also contains medicinal compounds, including polysaccharides, steroids, and lipids $(2,3)$. Shiitake mushroom have also been used as an alternative medicine in Korea, China, Japan and eastern Russia (4).

Shiitake mushrooms grow in various deciduous trees in warm and moist climates. They grow naturally throughout Southeastern Asia, but at present, most are artificially cultivated using logs (5). However, unlike other mushrooms,

*Corresponding author. E-mail : wonyoung@knu.ac.kr Phone : 82-53-950-7763, Fax : 82-53-950-7762

Received 20 November 2018; Revised 21 February 2019; Accepted 22 February 2019.

Copyright (c) The Korean Society of Food Preservation. All rights reserved. shiitake mushrooms have a limited production time, and it is difficult to store them for an extended period of time because of their rapid metabolic reaction after harvest. Therefore, shiitake mushrooms are commonly hot- air dried after harvesting for storage and transportation to the consumer. However freshly harvested mushrooms are preferred over dried mushrooms. Therefore, many studies have tried to improve on the storage longevity of fresh shiitake mushrooms $(6,7)$.

A number of studies have been conducted to improve the storage conditions of foods, including controlled atmosphere storage, modified atmosphere storage, coating methods, and vacuum pre-cooling (8-12). Among them, modified atmosphere packaging (MAP) prevents contamination and oxidation of the food. It is also widely used because it can reduce the need to add exogenous preservatives and it can extend the shelf life of food without altering its physical and chemical properties. The gases used for MAP are primarily oxygen, carbon dioxide and nitrogen $(13,14)$. Argon has also frequently been used in MAP studies (15), and it has become a licensed MAP gas in the European Union due to its inert, 
odorless and tasteless characteristics (16).

Argon is much more soluble in water and oil than nitrogen and it efficiently displaces dissolved oxygen (17). Hence, it effectively controls respiration. Previous studies have shown that high-quality argon treatment reduces microbial growth and improves the quality of stored apples (18).

However, there is limited data on the use of argon gas for the storage of shiitake mushrooms using MAP $(19,20)$. Therefore, this study investigated the effect of MAP on the quality of shiitake mushrooms during storage

\section{Materials and Methods}

\section{Sample preparation}

Shiitake mushrooms were purchased from a mushroom farm in Seongju, Korea. The mushrooms were precooled for one day at $5^{\circ} \mathrm{C}$ before use. The mushrooms $(110 \pm 20 \mathrm{~g})$ were packed in a polyamide-polyethylene package (VBS3040, Solis, Glattbrugg-Zurich, Switzerland) using a vacuum packaging machine (AZ-450E, Intrise Co. Ltd, Ansan, Korea). After evacuation, the packages were filled with different gases. The MAP gas composition is presented in Table 1. Packaged samples were then stored for 21 days at 5 and $15^{\circ} \mathrm{C}$.

\section{Gas composition}

The composition of gas in the package was measured using a digital gas analyzer (Quantek Gas Analyzer Model 902D, Quantek Instruments Inc., Massachusetts, USA) and the result displayed as percent $\mathrm{O}_{2}$ and percent $\mathrm{CO}_{2}$ concentrations. The $\mathrm{O}_{2}$ consumed and $\mathrm{CO}_{2}$ produced were calculated as follows:

$\mathrm{O}_{2}$ consumption $(\%)=\mathrm{O}_{2 \text { fin }}-\mathrm{O}_{2 \text { in }}$ $\mathrm{CO}_{2}$ production $(\%)=\mathrm{CO}_{2 \mathrm{fin}}-\mathrm{CO}_{2 \text { in }}$

$\mathrm{O}_{2 \text { in }}$ and $\mathrm{O}_{2 \text { fin }}$ are oxygen concentration at initial storage time ( 0 day) and final storage time, respectively.

$\mathrm{CO}_{2 \text { in }}$ and $\mathrm{CO}_{2 \text { fin }}$ are carbon dioxide concentration at initial storage time (0 day) and final storage time, respectively.

\section{Weight loss}

Weight loss was calculated using the weight before and after storage.

$$
\text { Weightloss }(\%)=\frac{A-B}{A} \times 100
$$

A: weight before storage (g)

B: weight after storage (g)

\section{Color}

The color of the mushroom was determined using a chroma meter (CR-300, Minolta Co., Osaka, Japan). Two parts of the mushroom (caps and gills) were examined. The experiment was repeated six times and the results expressed as $L^{*}$ values.

\section{Texture}

The texture of the mushrooms was measured using a rheometer (Compac-100D, Sun Scientific Co., Tokyo, Japan) with a round probe $(20 \mathrm{~mm})$ and table speed of $60 \mathrm{~mm} / \mathrm{min}$. The middles of the mushroom caps were cut into pieces $\left(20 \times 20 \times 12 \mathrm{~cm}^{3}\right)$ for use in the experiment. The sample compression was set to $50 \%$, and the experiment was repeated five times.

\section{Polyphenol oxidase}

Polyphenol oxidase (PPO) was analyzed using the method of Pizzocaro et al. (21) with some modifications. A $10 \mathrm{~g}$ sample was homogenized with $10 \mathrm{~mL}$ McIlvaine citric-phosphate buffer ( $\mathrm{pH} \mathrm{5)}$. The homogenized sample was centrifuged at $10,000 \mathrm{rpm}$ for $20 \mathrm{~min}\left(4^{\circ} \mathrm{C}\right)$. The supernatant $(0.1 \mathrm{~mL})$ was mixed with $2 \mathrm{~mL} 0.1 \%$ catechol and $2 \mathrm{~mL}$ McIlvaine citric-phosphate buffer. The PPO activity was determined using a UV spectrophotometer (Shimazdu Co. UV-2550, Tokyo, Japan) at $420 \mathrm{~nm}$. The result was expressed as PPO activity (unit/min/g).

\section{Microbiological analysis}

The samples $(15 \mathrm{~g})$ were mixed with $135 \mathrm{~mL}$ of $0.1 \%$ peptone water in a sterile filter bag (sample bag 1930F, $190 \times 300 \mathrm{~mm}, 3 \mathrm{M}$, Yeoju, Korea). The samples were blended using stomacher (SH-001, Shimskyu, Tokyo, Japan) for 2 min. After diluting the filtrate using $0.1 \%$ peptone water, the aliquots were inoculated on plate count agar (Difco-Becton Dickinson, Maryland, USA). The plates were incubated at $36^{\circ} \mathrm{C}$ for $48 \mathrm{~h}$.

\section{Statistical analysis}

The results were expressed as the average and standard deviation. SPSS software (SPSS Inc., Chicago, IL, USA) was used for statistical analysis including Duncan's multiple range tests. 


\section{Results and Discussion}

\section{Gas composition}

The storage temperature and gas composition were observed to affect the consumption of $\mathrm{O}_{2}$ and the production of $\mathrm{CO}_{2}$ (Fig. 1). $\mathrm{O}_{2}$ consumption decreased and $\mathrm{CO}_{2}$ production increased for all storage conditions. Mushrooms stored at $5^{\circ} \mathrm{C}$ had lower $\mathrm{O}_{2}$ consumption and consequently produced lower $\mathrm{CO}_{2}$ compared with mushrooms stored at $15^{\circ} \mathrm{C}$. The gas composition in the MAP has also been reported to be a key factor in storage experiments because high $\mathrm{CO}_{2}$ and low $\mathrm{O}_{2}$ levels influence the reduction of respiration rate (22). From the result of this study, it can be seen that low $\mathrm{O}_{2}$ and high $\mathrm{CO}_{2}$ composition in both the $\mathrm{Ar}$ and N MAP were effective in lowering metabolic processes, whereas, high $\mathrm{O}_{2}(20.9 \%)$ in the control (C) packaging resulted in a higher respiration rate, which led to rapid spoilage. For example, after 4 days, samples stored in the $\mathrm{C}$ packaging showed high $\mathrm{O}_{2}$ consumption with values of $7.87 \%$, and $19.6 \%$ at 5 and $15^{\circ} \mathrm{C}$, respectively, and consequently increased values for $\mathrm{CO}_{2}$ production of $15.94 \%$ and $46.90 \%$ at 5 and $15^{\circ} \mathrm{C}$, respectively.

Different optimal $\mathrm{CO}_{2}$ and $\mathrm{O}_{2}$ concentrations for shiitake mushrooms have been reported in different studies. Minamida et al. (23) reported that $40 \% \mathrm{CO}_{2}$ and $1 \% \mathrm{O}_{2}$ prolonged the shelf life of shiitake mushroom. Parentelli et al. (24) suggested $\mathrm{CO}_{2}$ levels for shiitake mushrooms below $2 \%$. However, our present study used a $\mathrm{CO}_{2}$ concentration of about $17 \%$ and
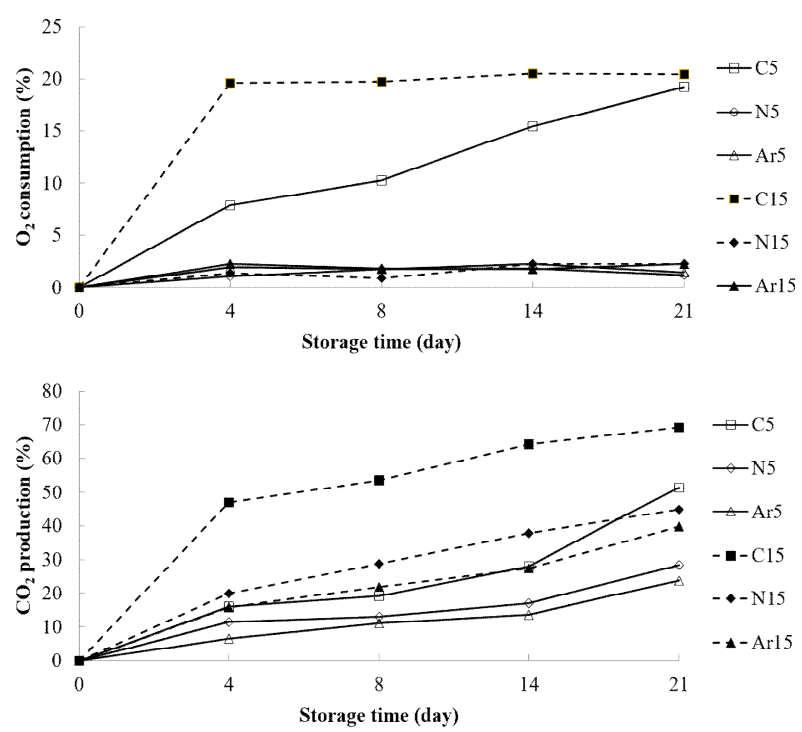

Fig. 1. Oxygen consumption and carbon dioxide production of shiitake mushroom according to storage temperature and MAP conditions.

Values are means \pm standard deviation $(\mathrm{n}=3)$.

$\mathrm{C}\left(\mathrm{N}_{2}: 78.1 \%\right.$, Ar: $\left.0.9 \%, \mathrm{O}_{2}: 20.9 \%, \mathrm{CO}_{2}: 0.03 \%\right), \mathrm{N}\left(\mathrm{N}_{2}: 80 \%, \mathrm{O}_{2}: 2.6 \%, \mathrm{CO}_{2}: 17.3 \%\right)$, $\operatorname{Ar}\left(\right.$ Ar: $80 \%, \mathrm{O}_{2}: 2.6 \%, \mathrm{CO}_{2}: 17.3 \%$ ). an $\mathrm{O}_{2}$ concentration below 3\% for the Ar and N MAP. Among the MAP conditions, Ar showed the lowest respiration rate, having the lowest $\mathrm{CO}_{2}$ production during storage. Utilization of $\mathrm{Ar}$ in MAP significantly extends the mushroom storage, as it is believed that argon limits metabolism by gas hydrate formation and residual gas in tissue, which restricts water activity and enzymes (25).

\section{Weight loss}

Loss of moisture in mushrooms is a degrading factor that causes detrimental effects such as tissue shrinkage, resulting in excessive weight loss (26). Fig. 2 shows the weight loss of the mushrooms under different conditions. Weight loss occurred throughout the storage time regardless of the packaging conditions employed, though the extent depended temperature and MAP conditions. Lagnika et al (26) reported that argon treatment reduced weight loss in mushroom during storage time. It is assumed that clathrate hydrate formation by high argon pressure can decrease the water loss owing to the hydrogen bonds between water molecules (26). However, there was no significant difference in weight loss between MAP conditions ( $\mathrm{p}>0.05)$. Weight loss as a result of storage temperature was $2.84-3.7 \%$ and $5.39-6.01 \%$ at 5 and $15^{\circ} \mathrm{C}$, respectively. It can be inferred from this result that weight loss is reduced at a lower temperature. The effect of high temperature on weight loss may be due to the increase

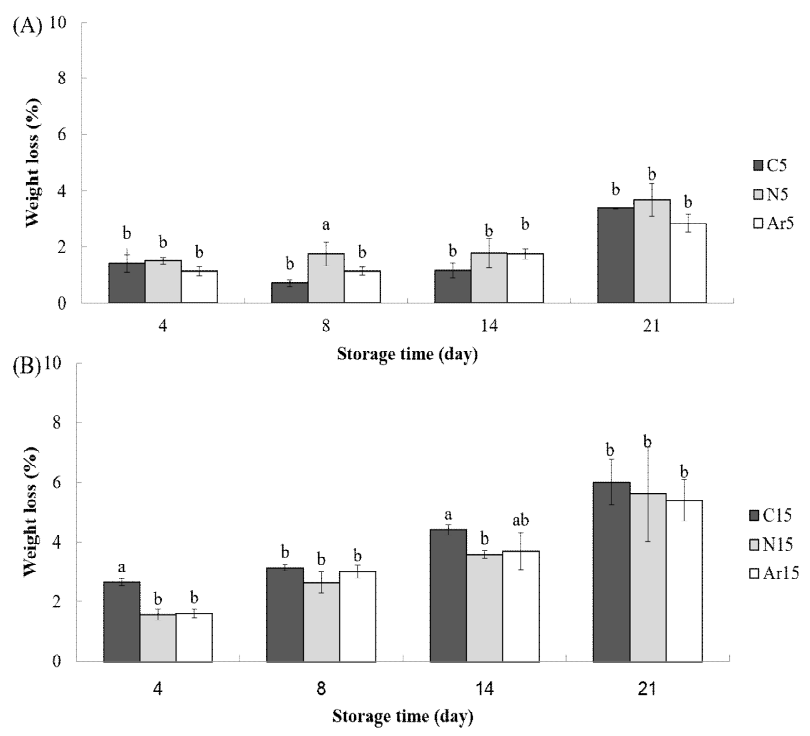

Fig. 2. Changes in weight loss of shiitake mushroom according to storage temperature and MAP conditions.

A, stored at $5^{\circ} \mathrm{C}$; B, stored at $15^{\circ} \mathrm{C}$

Values are means \pm standard deviation $(\mathrm{n}=3)$. Means followed by the different letters in same storage day are significantly different by Duncan's multiple range test $(\mathrm{p}<0.05)$. $\mathrm{C}\left(\mathrm{N}_{2}: 78.1 \%\right.$, Ar: $\left.0.9 \%, \mathrm{O}_{2}: 20.9 \%, \mathrm{CO}_{2}: 0.03 \%\right), \mathrm{N}\left(\mathrm{N}_{2}: 80 \%, \mathrm{O}_{2}: 2.6 \%, \mathrm{CO}_{2}: 17.3 \%\right)$, Ar (Ar: $80 \%, \mathrm{O}_{2}: 2.6 \%, \mathrm{CO}_{2}: 17.3 \%$ ). 
in the vapor transmission rate of the film, as well as the transpiration and respiration rate of the mushrooms (27). Tano et al (28) also reported that high temperature accelerated weight loss.

\section{Color}

The color of a mushroom is an important factor in consumer acceptance and marketability. The color of the caps and gills were expressed as the $L^{*}$ value which represents the brightness of the sample. Browning in mushrooms, indicated by a decreasing $L^{*}$ value (29), is assumed to be a direct consequence of PPO action on polyphenols (30). Fig. 3 displays the color values of the caps and gills. The $\mathrm{L}^{*}$ values of the caps and gills decreased during storage at both temperatures. However, mushroom storage at $5^{\circ} \mathrm{C}$ was observed to limit reduction in $\mathrm{L}^{*}$ values. The mushrooms stored at $5^{\circ} \mathrm{C}$ showed the highest $L^{*}$ values after 21 days. Among the MAP conditions, Ar showed a higher $\mathrm{L}^{*}$ value for mushroom caps than $\mathrm{N}$ or $\mathrm{C}$ MAP after 21 days at $5^{\circ} \mathrm{C}$. The gas type did not affect the brightness of the gills at

(A)

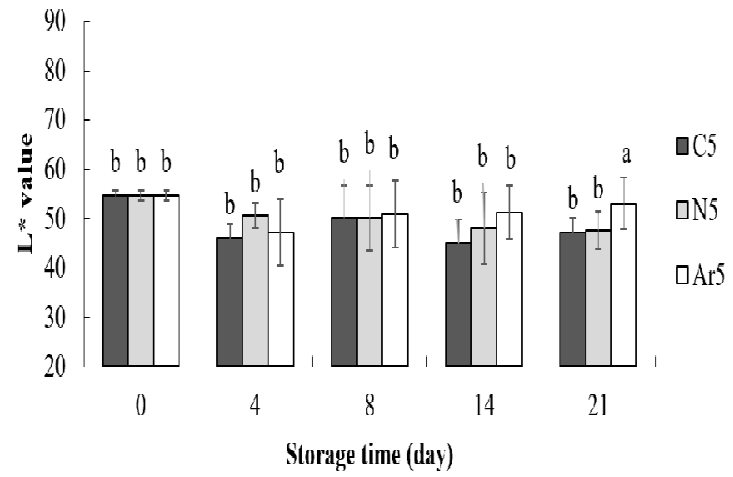

(C)

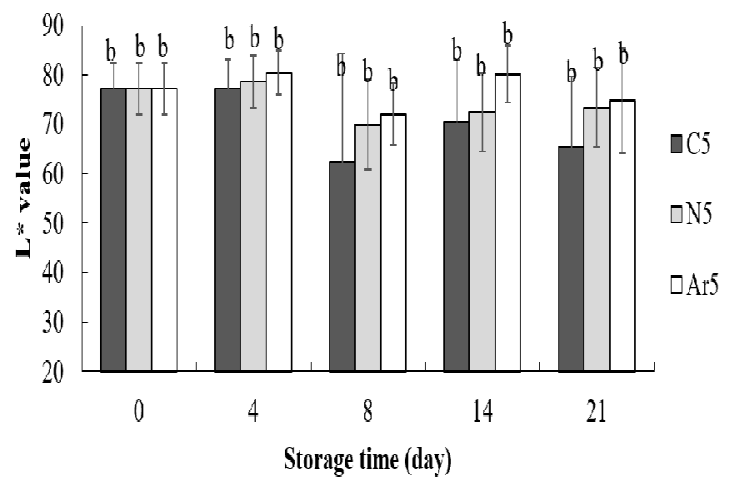

$5^{\circ} \mathrm{C}$. However, the Ar and N MAP showed higher $\mathrm{L}^{*}$ values for the gills after 14 days at $15^{\circ} \mathrm{C}$.

\section{Texture}

One of the main characteristics associated with mushrooms deterioration is changes in texture during storage. The influence of storage temperature and MAP conditions on the texture represented by hardness value is presented in Fig. 4. At $5^{\circ} \mathrm{C}$, mushrooms stored in the Ar MAP showed higher hardness than other packaging conditions from day 14 until the end of the evaluated storage time at day 21. Similar results have been reported on the influence of argon MAP conditions in the maintenance of the initial firmness of kiwifruit (31). At a storage temperature of $15^{\circ} \mathrm{C}$, mushrooms in the $\mathrm{Ar}$ and $\mathrm{N}$ MAP maintained higher hardness throughout storage than those in $\mathrm{C}$ packaging. The biochemical reactions responsible for mushroom tissue degradation are inhibited by atmospheres lower in $\mathrm{O}_{2}$ and higher in $\mathrm{CO}_{2}$ than air (22). Previous studies have reported that high $\mathrm{CO}_{2}$ concentrations seem to play a key role in preserving the textural properties of mushroom

(B)

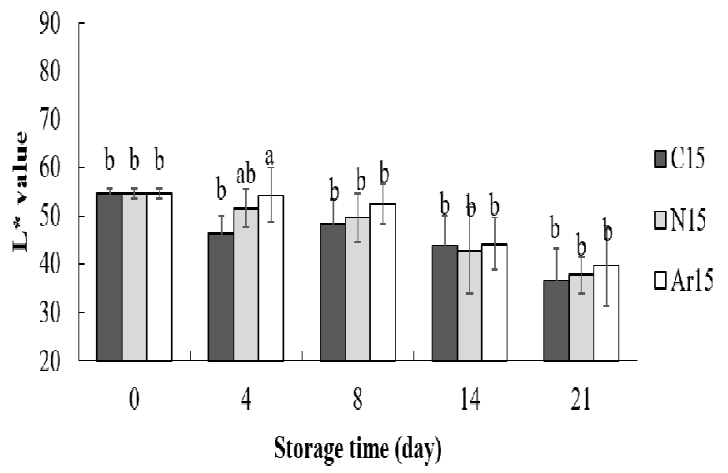

(D)

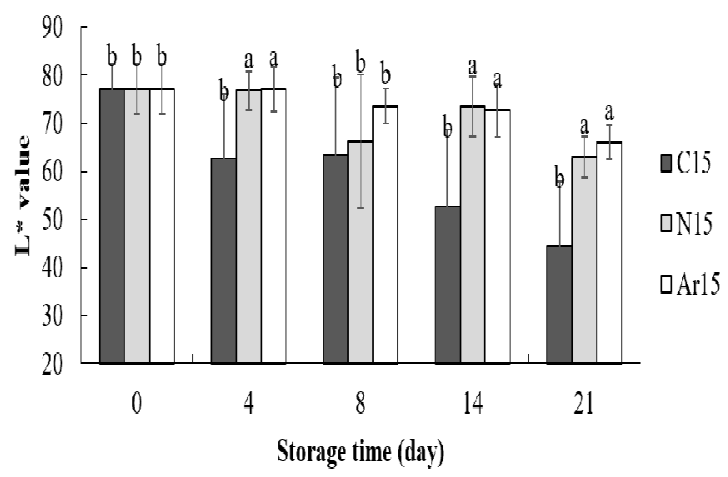

Fig. 3. Changes in $\mathrm{L}$ value of shiitake mushroom according to storage temperature and MAP conditions.

Values are means \pm SD $(n=6)$. Means followed by the different letters in same storage day are significantly different by Duncan's multiple range test ( $<<0.05$ ). (A) Caps at $5^{\circ} \mathrm{C}$, (B) Caps at $15^{\circ} \mathrm{C}$, (C) Gills at $5^{\circ} \mathrm{C}$, (D) Gills at $15^{\circ} \mathrm{C}$.

$\mathrm{C}\left(\mathrm{N}_{2}: 78.1 \%, \operatorname{Ar}: 0.9 \%, \mathrm{O}_{2}: 20.9 \%, \mathrm{CO}_{2}: 0.03 \%\right), \mathrm{N}\left(\mathrm{N}_{2}: 80 \%, \mathrm{O}_{2}: 2.6 \%, \mathrm{CO}_{2}: 17.3 \%\right), \operatorname{Ar}\left(\mathrm{Ar}: 80 \%, \mathrm{O}_{2}: 2.6 \%, \mathrm{CO}_{2}: 17.3 \%\right)$. 
(32-35). The hardness of the mushrooms decreased more rapidly at $15^{\circ} \mathrm{C}$ than at $5^{\circ} \mathrm{C}$. A relationship between texture and storage temperature can be seen from this result, as the mushroom texture was preserved more at lower temperature. Mushroom softening or loss of hardness during storage has been ascribed to changes in the membrane (36). According to Zivanovic et al (37), texture changes are also related to protein and polysaccharide degradation, hyphae shrinkage, central vacuole disruption and expansion of intercellular space at the pilei surface.
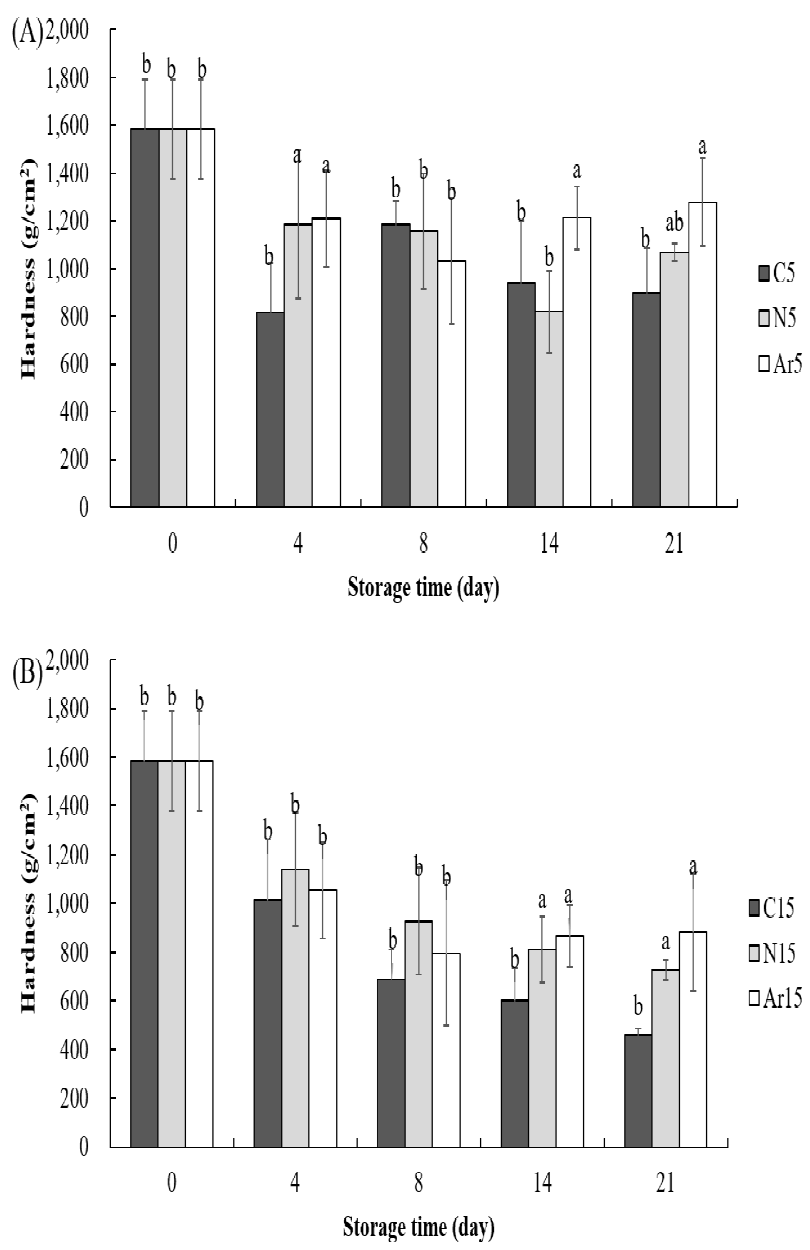

Fig. 4. Changes in hardness of shiitake mushroom according to storage temperature and MAP conditions.

Values are means \pm SD $(n=5)$. Means followed by the different letters in same storage day are significantly different by Duncan's multiple range test $(\mathrm{p}<0.05)$.

$\mathrm{C}\left(\mathrm{N}_{2}: 78.1 \%\right.$, Ar: $\left.0.9 \%, \mathrm{O}_{2}: 20.9 \%, \mathrm{CO}_{2}: 0.03 \%\right), \mathrm{N}\left(\mathrm{N}_{2}: 80 \%, \mathrm{O}_{2}: 2.6 \%, \mathrm{CO}_{2}: 17.3 \%\right)$, Ar (Ar: $80 \%, \mathrm{O}_{2}: 2.6 \%, \mathrm{CO}_{2}: 17.3 \%$ )

\section{Polyphenol oxidase}

PPO is known as an enzyme related to mushroom browning (38). The PPO results as affected by the storage temperatures and MAP conditions are shown in Fig. 5. The PPO activity increased with an increase in storage temperature. There were no differences in PPO activity between MAP conditions at $5^{\circ} \mathrm{C}$. However, Ar and N MAP both inhibited PPO activity at $15^{\circ} \mathrm{C}$. When the mushrooms were stored at $15^{\circ} \mathrm{C}$ for 21 days, the PPO activity of the mushrooms stored under $\mathrm{C}$ packaging increased $(21.67 \mathrm{U} / \mathrm{min})$, but those stored in $\mathrm{Ar}$ and N MAP were 14.15 and $12.29 \mathrm{U} / \mathrm{min}$, respectively. Overall, mushrooms in the Ar MAP showed lower PPO activity than those in the N MAP at $15^{\circ} \mathrm{C}$. A similar result was obtained by Bae et al. (39). Spencer et al. (40) claimed that the high atomic mass of noble gases facilitated the inhibition of PPO activity. O'Beirne et al (41) reported that argon was more effective at reducing PPO activity than nitrogen and suggested that the inhibitory effect of argon gas resulted from its high Van der Waals radius.
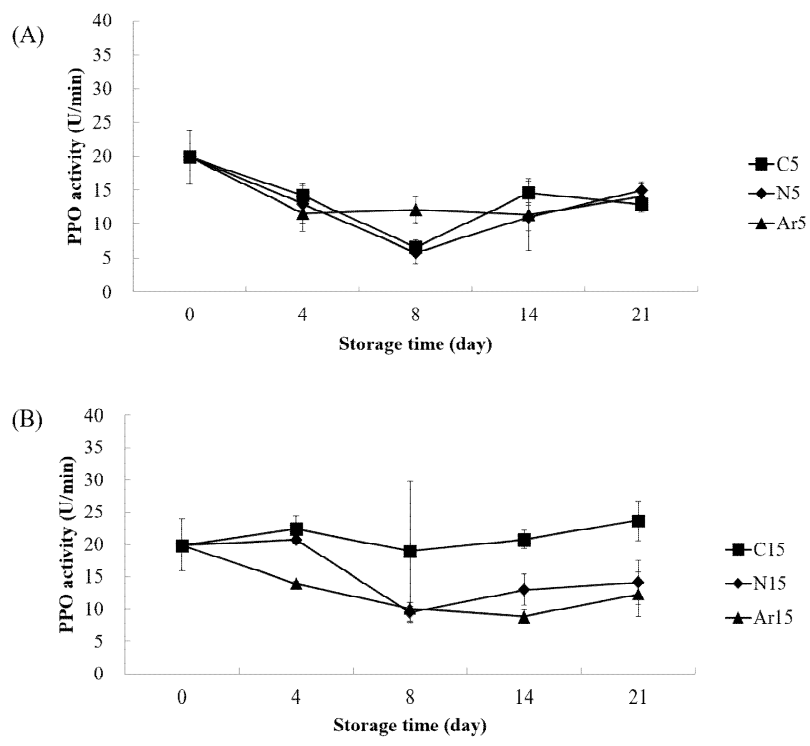

Fig. 5. Changes in polyphenol oxidase (PPO) activity of shiitake mushroom according to storage temperature and MAP conditions. Values are means \pm standard deviation $(\mathrm{n}=3)$.

(A) stored at $5^{\circ} \mathrm{C}$, (B) stored at $15^{\circ} \mathrm{C}$.

C $\left(\mathrm{N}_{2}: 78.1 \%\right.$, Ar: $\left.0.9 \%, \mathrm{O}_{2}: 20.9 \%, \mathrm{CO}_{2}: 0.03 \%\right), \mathrm{N}\left(\mathrm{N}_{2}: 80 \%, \mathrm{O}_{2}: 2.6 \%, \mathrm{CO}_{2}: 17.3 \%\right)$, Ar (Ar: $80 \%, \mathrm{O}_{2}: 2.6 \%, \mathrm{CO}_{2}: 17.3 \%$ ).

Table 1. Gas composition in the packaging for modified atmosphere packaging

\begin{tabular}{cccc}
\hline \multirow{3}{*}{ Gas types } & \multicolumn{3}{c}{ Treatment } \\
\cline { 2 - 4 } & $\mathrm{C}^{1)}$ & $\mathrm{N}$ & $\mathrm{Ar}$ \\
\hline $\mathrm{N}_{2}(\%)$ & 78.1 & 80 & 0 \\
$\mathrm{Ar}(\%)$ & 0.9 & 0 & 80 \\
$\mathrm{O}_{2}(\%)$ & 20.9 & 2.6 & 2.6 \\
$\mathrm{CO}_{2}(\%)$ & 0.03 & 17.3 & 17.3 \\
\hline
\end{tabular}

${ }^{1)} \mathrm{C}\left(\mathrm{N}_{2}: 78.1 \%\right.$, Ar: $\left.0.9 \%, \mathrm{O}_{2}: 20.9 \%, \mathrm{CO}_{2}: 0.03 \%\right), \mathrm{N}\left(\mathrm{N}_{2}: 80 \%, \mathrm{O}_{2}: 2.6 \%, \mathrm{CO}_{2}\right.$ : 17.3\%), Ar (Ar: 80\%, $\mathrm{O}_{2}: 2.6 \%, \mathrm{CO}_{2}: 17.3 \%$ ). 


\section{Microbial growth}

Microbial growth rate is an important parameter in food safety because it influences product qualities such as texture and freshness (42). Furthermore, toxic substances can be produced if the microbial count goes beyond $6.0 \log \mathrm{CFU} / \mathrm{g}$ (43). The change in microbial growth during storage is shown in Table 2. The initial microbial count was $0.58 \mathrm{log} \mathrm{CFU} / \mathrm{g}$. The microbial count at 5 and $15^{\circ} \mathrm{C}$, was $2.13-2.51$ and 2.76-2.85 log CFU/g, respectively. Microbial growth greatly increased over 0-4 days, then decreased after 4 days. The microbial count increased with increasing storage temperature. Overall, MAP conditions did not affect the microbial growth of the mushrooms throughout 21 days of storage at 5 and $15^{\circ} \mathrm{C}$, which contradicts some reports that argon had a good effect on suppressing microbial growth at low temperatures $(26,44)$.

It is assumed that contamination might have been caused by moisture in the package due to transpiration in this study. To reduce contamination by condensed water, further study to reduce transpiration is required. retained hardness during storage. Mushrooms in the Ar and $\mathrm{N}$ MAP maintained gill brightness at $15^{\circ} \mathrm{C}$. We therefore identified the Ar MAP as being effective for improving the shelf-life of mushrooms. However, moisture condensed in the package because of transpiration. That moisture might cause rapid corruption and quality loss. Therefore, further study is needed to reduce transpiration in the package.

\section{References}

1. Han KY (2015) Effect of storage temperature, time and natural additives on the changes in flavor of lentinus edodes. J Korean Culinary Research, 21, 235-249

2. Wang X, Zhang L (2009) Physicochemical properties and antitumor activities for sulfated derivatives of lentinan. Carbohydr Res, 344, 2209-2216

3. Wasser SP (2002) Medicinal mushrooms as a source of antitumor and immunomodulating polysaccharides. Appl Microbiol Biotechnol, 60, 258-274

Table 2. Change of microbial count of shiitake mushroom according to storage temperature and MAP conditions

\begin{tabular}{|c|c|c|c|c|c|c|}
\hline \multirow{2}{*}{$\begin{array}{l}\text { Storage temperature } \\
\qquad\left({ }^{\circ} \mathrm{C}\right)\end{array}$} & \multirow{2}{*}{ Treatment } & \multicolumn{5}{|c|}{ Microbial count $(\log \mathrm{CFU} / \mathrm{g})$} \\
\hline & & 0 & 4 & 8 & 14 & 21 \\
\hline \multirow{3}{*}{5} & $C^{2)}$ & $0.58 \pm 0.10^{1)}$ & $2.51 \pm 0.19$ & $2.69 \pm 0.68$ & $3.53 \pm 0.40$ & $2.91 \pm 0.12$ \\
\hline & $\mathrm{N}$ & $0.58 \pm 0.10$ & $2.25 \pm 0.36$ & $2.36 \pm 0.40$ & $3.01 \pm 0.13$ & $2.91 \pm 0.41$ \\
\hline & $\mathrm{Ar}$ & $0.58 \pm 0.10$ & $2.12 \pm 0.30$ & $2.63 \pm 0.75$ & $2.87 \pm 0.44$ & $3.18 \pm 0.18$ \\
\hline \multirow{3}{*}{15} & $\mathrm{C}$ & $0.58 \pm 0.10$ & $2.85 \pm 0.49$ & $3.24 \pm 0.11$ & $3.60 \pm 0.38$ & $3.73 \pm 0.63$ \\
\hline & $\mathrm{N}$ & $0.58 \pm 0.10$ & $2.77 \pm 0.21$ & $3.10 \pm 0.24$ & $3.27 \pm 0.83$ & $4.41 \pm 1.03$ \\
\hline & $\mathrm{Ar}$ & $0.58 \pm 0.10$ & $2.76 \pm 0.40$ & $3.05 \pm 0.12$ & $3.39 \pm 0.15$ & $3.72 \pm 1.15$ \\
\hline
\end{tabular}

${ }^{1)}$ Values are means $\pm \mathrm{SD}(\mathrm{n}=3)$.

${ }^{2} \mathrm{C}\left(\mathrm{N}_{2}: 78.1 \%, \mathrm{Ar}: 0.9 \%, \mathrm{O}_{2}: 20.9 \%, \mathrm{CO}_{2}: 0.03 \%\right), \mathrm{N}\left(\mathrm{N}_{2}: 80 \%, \mathrm{O}_{2}: 2.6 \%, \mathrm{CO}_{2}: 17.3 \%\right)$, $\mathrm{Ar}\left(\operatorname{Ar}: 80 \%, \mathrm{O}_{2}: 2.6 \%, \mathrm{CO}_{2}: 17.3 \%\right)$.

\section{Conclusion}

Mushrooms were stored under different temperatures and MAP conditions. Storage temperature greatly influenced the quality of the mushrooms. Mushrooms stored at $5^{\circ} \mathrm{C}$ showed lower $\mathrm{O}_{2}$ consumption, $\mathrm{CO}_{2}$ production, decay rate, color change, and weight loss compared with those stored at $15^{\circ} \mathrm{C}$. Weight loss and microbial count did not show significant differences depending on the MAP conditions. However, mushrooms stored in $\mathrm{Ar}$ and $\mathrm{N}$ MAP presented lower $\mathrm{O}_{2}$ consumption, $\mathrm{CO}_{2}$ production and decay rates compared with those stored in $\mathrm{C}$ packaging. Ar and N MAP inhibited PPO activity in mushroom at $15^{\circ} \mathrm{C}$. Mushrooms in the Ar MAP
4. Lull C, Wichers HJ, Savelkoul HFJ (2005) Antiinflammatory and immunomodulating properties of fungal metabolites. Mediators Inflammation, 2005, 63-80

5. Chen AW (2001) Cultivation of lentinula edodes on synthetic logs. Mushroom Growers' Newsletter, 10, 3-9

6. Hwang YS, Seo GS (2013) Storage potential of low temperature adapted shiitake mushroom under freezing temperature. Korean J Agric Sci, 40, 197-202

7. Hwang YS (2000) Improvement of fresh shiitake storage under freezing temperature and marketing. Final Report of MAFRA, TRKO201100002475

8. Briones GL, Varoquaux P, Chambroy Y, Bouquant J, Bureau G, Pascat B (1992) Storage of common mushroom 
under controlled atmospheres. Int J Food Sci Tech, 27, 493-505

9. Stiles ME (1990) Modified atmosphere packaging of meat, poultry and their products. In: Modified atmosphere packaging of food, Stiles ME (Editor), Springer, Boston, USA, p 118-147

10. El Ghaouth A, Ponnampalam R, Castaigne F, Arul J (1992) Chitosan coating to extend the storage life of tomatoes. HortScience, 27, 1016-1018

11. Narasimha Rao D, Sachindra NM (2002) Modified atmosphere and vacuum packaging of meat and poultry products. Food Rev. Int, Vol 18, $263-293$

12. Lee WO, Yoon HS, Jung H, Lee HD, Lee KH (2002) Vacuum pre-cooling of agricultural products. KR Patent No. $10-0470637$

13. Raimondi S, Luciani R, Sirangelo TM, Amaretti A, Leonardi A, Ulrici A, Foca G, D’Auria G, Moya A, Zuliani V, Seibert TM, Soeltoft-Jensen J, Rossi M (2019) Microbiota of sliced cooked ham packaged in modified atmosphere throughout the shelf life Microbiota of sliced cooked ham in MAP. Int J Food Microbiol, 289, 200-208

14. Farber JM (1991) Microbiological aspects of modified-atmosphere packaging technology $-\mathrm{A}$ review. J Food Prot, 54, 58 - 70

15. Spencer KC, Humphreys DJ (2003) Argon packaging and processing preserves and enhances flavor, freshness and shelf life of foods. Freshness and Shelf Life of Foods, 836, 270-291

16. Herbert U, Rossaint S, Khanna MA, Kreyenschmidt J (2013) Comparison of argon-based and nitrogen-based modified atmosphere packaging on bacterial growth and product quality of chicken breast fillets. Poult. Sci, 92, 1348-1356

17. Lagnika C, Zhang M, Mothibe K. J (2013) Effects of ultrasound and high pressure argon on physico-chemical properties of white mushrooms (Agaricus bisporus) during postharvest storage. Postharvest Biol Technol, 82, 87-94

18. Wu ZS, Zhang M, Wang S (2012) Effects of high pressure argon treatments on the quality of fresh-cut apples at cold storage. Food Control, 23, 120-127

19. Son HJ, Moon KD (2014) Effects of combined argon gas treatment on the quality of fresh-cut potatoes. Korean J Food Preserv, 21, 163-169

20. Pardilla S, Mor-Mur M, Vega LF, Guri S (2013) Argon and high content of $\mathrm{CO}_{2}$ : the future for fresh-cut apples packaged in MAP. Acta Hortic, 1071, 731-737
21. Pizzocaro F, Torreggiani D, Gilardi G (1993) Inhibition of apple polyphenoloxidase (PPO) by ascorbic acid, citric acid and sodium chloride. J Food Process Preserv, 17, 21-30

22. Antmann G, Ares G, Lema P, Lareo C (2008) Influence of modified atmosphere packaging on sensory quality of shiitake mushrooms. Postharvest Biol Technol, 49, 164-170

23. Minamida T, Nishikawa T, Ogata K (1980) Influences of $\mathrm{CO}_{2}$ and $\mathrm{O}_{2}$ on the keeping freshness of shii-take (Lentinus edodes (Berk) Sing.) after harvest. Nippon Shokuhin Kogyo Gakkaishi, 27, 505-510

24. Parentelli C, Ares G, Corona M, Lareo C, Gambaro A, Soubes M, Lema P (2007) Sensory and microbiological quality of shiitake mushrooms in modified atmosphere packages. J Sci Food Agric, 87, 1645-1652

25. Zhan ZG, Zhang M (2005) Effects of inert gases on enzyme activity and inspiration of cucumber. J Food Biotechnol, 24, 16-18

26. Lagnika C, Zhang M, Wang S (2011) Effect of high argon pressure and modified atmosphere packaging on the white mushroom (Agaricus bisporus) physico-chemical and microbiological properties. J Food Nutr Res, 50, 167 - 176

27. Roy S, Anantheswaran RC, Beelman RB (1995) Fresh mushroom quality as affected by modified atmosphere packaging. J Food Sci, 60, 334-340

28. Tano K, Arul J, Doyon G, Castaigne F (1999) Atmospheric composition and quality of fresh mushrooms in modified atmosphere packages as affected by storage temperature abuse. J Food Sci, 64, 1073-1077

29. Jamjumroon S, Wongs-Aree C, McGlasson WB, Srilaong V, Chermklin P, Kanlayanarat S (2013) Alleviation of cap browning of 1-MCP/high $\mathrm{CO}_{2}$-treated straw mushroom buttons under MAP. Int Food Res J, 20, 581-585

30. Jolivet S, Arpin N, Wichers HJ, Pellon G (1998) Agaricus bisporus browning: a review. Mycol Res, 102, 1459-1483

31. Rocculi P, Romani S, Dalla Rosa M (2005) Effect of MAP with argon and nitrous oxide on quality maintenance of minimally processed kiwifruit. Postharvest Biol Technol, 35, 319-328

32. Briones GL, Varoquaux P, Bureau G, Pascat B (1993) Modified atmosphere packaging of common mushroom. Int J Food Sci Technol, 28, 57-68

33. Fandos EG, Olarte C, Gimenez M, Sanz S, Simon A (2001) Behavior of Listeria monocytogenes in packaged 
fresh mushrooms (Agaricus bisporus). J Appl Microbiol, 91, 795-805

34. Simon A, Fandos EG, Tobar V (2005) The sensory and microbiological quality of fresh sliced mushroom (Agaricus bisporus L.) packaged in modified atmospheres. Int J Food Sci Technol, 40, 943-952

35. Gholami R, Ahmadi E, Farris S (2017) Shelf life extension of white mushrooms (Agaricus bisporus) by low temperatures conditioning, modified atmosphere, and nanocomposite packaging material. Food Packaging Shelf, 14, 88-95

36. Ares G, Lareo C, Lema P (2007) Modified atmosphere packaging for postharvest storage of mushrooms. A review. Fresh Produce, 1, 32-40

37. Zivanovic S, Busher RW, Kim KS (2000) Textural changes in mushrooms (Agaricus bisporus) associated with tissue ultrastructure and composition. J Food Sci, 65, 1404-1408

38. Ye JJ, Li JR, Han XX, Zhang L, Jiang TJ, Miao XIA (2012) Effects of active modified atmosphere packaging on postharvest quality of shiitake mushrooms (Lentinula edodes) stored at cold storage. J Integr Agric, 11, 474-482

39. Bae IY, Lee YJ, Kim ES, Lee SY, Park HG, Lee HG (2010) Effect of coating material and storage temperature on the quality characteristics of Lentinus edodes mushroom (Chamgsongi). Korean J Food Sci Technol, $42,682-687$
40. Spencer KC (1999) Fresh-cut produce-application of noble gases. Paper presented at the international conference on fresh-cut produce. Chipping Campden, September, UK

41. O'Beirne D, Murphy E, Eidhin DN (2011) Effects of argon enriched low oxygen atmospheres and of high oxygen atmospheres on the kinetics of polyphenoloxidase (PPO). J Food Sci, 76, 73-77

42. Cho SH, Chung JH, Ryu CH (1994) Inhibitory effects of natural antimicrobial agent on postharvest decay in fruits and vegetables under natural low temperatures. J Korean Soc Food Nutr, 23, 315-321

43. Lee JY, Park HJ, Lee CY, Choi WY (2003) Extending shelf-life of minimally processed apples with edible coatings and antibrowning agents. LWT Food Sci Technol, 36, 323-329

44. Claudia RC, Francisco JC (2010) Effect of an argon-containing packaging atmosphere on the quality of fresh pork sausages during refrigerated storage. Food Control. 21, 1331-1337 